\title{
Competitiveness of Indonesian Livestock Production among ASEAN Countries
}

\section{(Daya Saing Produksi Ternak Indonesia di Antara Negara-Negara ASEAN)}

\author{
Tjeppy D Soedjana ${ }^{1}$ and A Priyanti ${ }^{2}$ \\ ${ }^{1}$ Emeritus Prof. (R) Indonesian Center for Animal Research and Development \\ ${ }^{2}$ Indonesian Center for Animal Research and Development, Jl. Raya Pajajaran Kav. E-59, Bogor 16128 \\ atienpriyanti@yahoo.com
}

(Diterima 26 Agustus 2016 - Direvisi 27 Januari 2017 - Disetujui 27 Februari 2017)

\begin{abstract}
ASEAN is one of the fastest growing regional economic communities and its combined human population of around 600 million people. Heterogeneity of ASEAN member countries includes population size, cultural background, structure and development of the economy, and level of income. Agriculture is well known as one of the key engine of economic growth of the ASEAN member countries, seen from the fact that most of the countries in this region are strongly depend on this sector including animal production. The purpose of this paper is to discuss the competitiveness of Indonesian production costs of selected livestock products compared to other ASEAN member countries. The following member countries are at their first rank or competitiveness status for the livestock and poultry commodities, namely Cambodia for beef cattle, Malaysia for pigs, the Philippines for sheep and goats, and Thailand for broiler chickens. Indonesia with the highest poultry population in the region, compared to Thailand, Malaysia, and the Philippines has not yet performed as that good in terms of production costs. The position of Indonesia based on production cost was at the fourth rank for beef, third for sheep and goat, and fourth for broiler compared to other ASEAN member countries. Therefore, Indonesia should improve the efficiency production of livestock and poultry to achieve better competition status.
\end{abstract}

Key words: ASEAN, livestock, production, competitiveness

\begin{abstract}
ABSTRAK
ASEAN adalah salah satu komunitas masyarakat ekonomi regional dengan pertumbuhan ekonomi tercepat dan jumlah penduduk sekitar 600 juta orang. Heterogenitas negara anggota ASEAN meliputi jumlah populasi, latar belakang budaya, struktur dan perkembangan ekonomi, serta tingkat pendapatan. Pertanian dikenal sebagai indikator utama pertumbuhan ekonomi negara-negara anggota ASEAN, karena sangat bergantung pada sektor pertanian termasuk peternakan. Tujuan penulisan makalah ini adalah untuk membahas daya saing biaya produksi Indonesia untuk produk ternak dibandingkan dengan negara anggota ASEAN lainnya. Negara peringkat pertama status daya saing untuk komoditas peternakan, yaitu Kamboja untuk sapi potong, Malaysia untuk babi, Filipina untuk domba dan kambing, serta Thailand untuk ayam broiler. Indonesia dengan populasi unggas tertinggi di wilayah ini, masih menerapkan biaya produksi yang lebih tinggi dibandingkan dengan Thailand, Malaysia, dan Filipina. Posisi Indonesia berdasarkan biaya produksi berada pada peringkat keempat untuk daging sapi, ketiga untuk domba dan kambing, serta keempat untuk ayam pedaging dibandingkan dengan negara anggota ASEAN lainnya. Karena itu, Indonesia harus meningkatkan efisiensi produksi ternak untuk mencapai status persaingan yang lebih baik
\end{abstract}

Kata kunci: ASEAN, peternakan, produksi, daya saing

\section{INTRODUCTION}

Southeast Asian region is one of the fastest growing regional economic communities, which according to ASEAN statistic 2014 has population of more than 625 million people and relatively high employment share of agriculture sector (ASEAN 2014). In addition to that ASEAN member countries are diverse in many aspects includes population sizes, cultural backgrounds, structure, and development of the economies. Indonesia being the highest human population country in the region, with more than 250 million peoples, has about $52 \%$ of the people live in urban areas. This country also has $35 \%$ employment share in agricultural sector as opposed to Brunei, the least populated country in the region, with 500 thousand people and only 1,000 people were working in agricultural sector. Furthermore, Singapore as an island country with 4,5 million human population, almost entire population live in urban area, with only 2,000 of people working in agriculture sector. 
It is understandable that a country with a growing middle and high income household pushes the demand for high income elastic commodity such as livestock products. This includes particularly meat, which after all will stimulate the red and white meat industries to grow fast. Indonesia, being the largest country in the region in terms of human population, and with about $52 \%$ of urban population, is likely to have high potential demand for high protein food including livestock products. This situation creates an increasing pressure on the livestock subsector to meet the growing demand for a high-value animal protein (Matsumura 2011). Consequently, livestock subsector will grow in line with a combination of human population growth, rising incomes, and urbanization, since there is a strong positive relationship between increasing of income of a household and growing consumption of animal protein (European Union 2015).

In general, these particular households which categorized as middle and upper income household, have higher demand for meat, milk, and eggs along the tendency to reduce the expenditure on carbohydrate source foods. OECD-FAO (2015) further found that the major changes in the demand were observed in developing countries, where continued but slowing population growth, rising per capita incomes and urbanization all increase the demand for food. Rising incomes prompt consumers to diversify diets by increasing the consumption of animal protein relative to starches. For this reason, the prices of meat and dairy products are expected to be high relative to the prices of crops, while among crops, the prices of coarse grains, and oilseeds used for feed should rise relative to the prices of food staples.

Agriculture is well known as one of the key engine of economic growth of the ASEAN countries, seen from the fact that most of the countries in this region are strongly depend on this sector. In addition to that, due to the fact that Southeast Asia has a dynamic geographical characteristics of its tradition, ASEAN region has a variety of food and agriculture tradition, which makes a number of ASEAN member countries ranked as worldwide top exporters in agricultural products such as rice, fruits, vegetables, and coffee. ASEAN also has a role as a global leader in industrial corps like palm oil, rubber, and pepper, which therefore has strong trade links for these industrial products with other countries across the globe, particularly with countries who have established trade relationship with many ASEAN member states. This fact proofs that the development of the agriculture sector in the region will remain one of the most important area for economic growth under ASEAN cooperation (CEIC Data 2016).

According ASEAN (2008), significant progress has been made in the advancement of ASEAN's regional economic integration. The removal of formal restrictions in different areas, along with other facilitating domestic, and external factors, has contributed to growing trade and investment in the region. Intra-ASEAN tariffs have gone down significantly, and are now close to negligible in the case of Brunei, Indonesia, Malaysia, Philippines, Singapore, and Thailand (ASEAN6), although the real impact to business will depend on the degree of preference utilization. While growing relatively faster than the overall ASEAN trade, the performance of intra-ASEAN trade has been uneven across the priority integration sector. In particular, the growth in intraASEAN exports in 2007-2013 has been slower than that in extra-ASEAN exports in all but three priority integration sectors, the exceptions were fisheries, automotive, and electronic products.

There are five core elements of its single market and production base according to the (ASEAN 2008). They include free flow of goods, free flow of services, free flow of investment, free flow of capital, and free flow of skilled labor. In addition to that, systems of standards, quality assurance, accreditation, and measurement are crucial to promote greater efficiency and enhance cost effectiveness of production of intraregional imports and exports. Therefore, purpose of this paper is to discuss and compare the production costs of selected livestock products in each ASEAN member country to describe how competitiveness its products. In addition, using the producer prices information as a proxy for comparison between countries, it will identify which member country has the most cost effectiveness to produce red and white meats from selected livestock species, such as beef, sheep and goats, broiler, and pigs.

\section{INDICATOR OF COMPETITIVENESS FOR SELECTED LIVESTOCK COMMODITIES}

There are 10 member countries of ASEAN, namely Brunei, Cambodia, Indonesia, Lao PDR, Malaysia, Myanmar, Philippines, Singapore, Thailand, and Vietnam that could be used for some data analysis. Their important indices such as population, agricultural land, gross domestic product share of agriculture were taken from ASEAN (2014). Data from FAOSTAT (2014) were used for identifying livestock population and production, as well as producer's price for selected meat producing species such as beef cattle, sheep and goats, broiler and pigs. However, some information of member countries are unavailable. Producer's price data related to each country were used as a proxy for cost of production. This indicator was then used to compare the competitiveness livestock production among ASEAN member countries. Previously, using different indicators, Tangendjaja (2010) studied the competitiveness of Indonesia compared to other 
ASEAN countries in poultry production based on the data of 2004-2008.

The producer's price is defined as the amount receivable by the producer from the purchaser for a unit of a good or service produced as output minus any or similar deductible tax, invoiced to the purchaser (OECD 2005). It excludes any transport charges invoiced separately by the producer. It also excludes supplier's retail and wholesale margins and separately invoiced transport and insurance charges. A producer price is also considered as the average price or unit value received by farmers in the domestic market for a specific agricultural commodity produced within a specified 12-month period (FAOSTAT 2014). This price is measured at the farm gate, that is at the point where the commodity leaves the farm, and therefore does not incorporate the costs of transport and processing. Typically producer prices are seen as prices of input goods, which are used to produce final goods. Therefore, the producer price may be used as a proxy to the production cost of commodities being observed (Ready et al 2015). The producer price data series presented for selected livestock producing meat such as beef cattle, sheep and goats, broiler and pigs, presented in FAOSTAT were used as a basis for comparison. Since the data are expressed in the same currency unit (USD/ton), it helps in obtaining consistent data series from different member countries. In order to simplify the numbers for comparison, this study converted USD/ton as the unit of measurement of producer's price to USD $/ \mathrm{kg}$. Finally, countries are then ranked based on their competitiveness in terms of production costs for producing meat from beef cattle, sheep and goats, broiler and pigs.

Domestic resources cost (DRC) approach has been widely used to measure products competitiveness as a comparative advantage, however due to specific needs of policy analysis and its goal, therefore concepts and size of its competitiveness could be varied across geographically, products, and time dimension (Ambastha \& Momaya 2004; Bojnec \& Fertő 2012). Domestic inputs cost, revenue, and tradable input costs were factors that affected into DRC, where $0<\mathrm{DRC}<1$ indicated its products in a comparative competitiveness commodity (Monke \& Pearson 1989; Masters \& Winter-Nelson 1995). The DRC has been defined as the shadow value of non tradable factor inputs used in an activity per unit of tradable value added. Daryanto (2007; 2009; 2010) had reported this DRC approach to measure livestock competitiveness in Indonesia for beef cattle and poultry production.

\section{RESOURCES FOR COMPETITIVENESS AND COMPARATIVE ADVANTAGES DETERMINATION}

In general, human population growth in the region was considered high (1.3\%). Indonesia is a country with the largest population (250 million), among ASEAN member countries followed by the Philippines (almost 100 million), Vietnam (90 million), Thailand (68 million), and Myanmar (62 million). Other ASEAN countries have lower population, ranging from Brunei (0.5 million) to Malaysia (30 million). The highest population growth of $2.0 \%$ was observed in Lao PDR with population around 7 million. Among five countries with high human population, the Philippines has the highest population growth rate $(1.8 \%)$ compared to the average population growth of the region $1.3 \%$, and Thailand shows the least population growth of only $0.5 \%$ in the region (Table 1 ).

Livestock products are considered as high income elastic commodity; therefore, it is interesting to observe the proportion of urban population and GDP per capita in each member country. Urban population represents middle and upper income households, which are spending more of their incomes for livestock and horticulture products compared to carbohydrate source foods. Table 2 indicates that in 2013, potential consumers of livestock products are estimated to be high in Singapore with $100 \%$ of the population stay in the urban area, followed by Malaysia (73\%), Indonesia $(52 \%)$, while other member countries have less than $50 \%$ of their urban population.

The population distribution can also be used to estimate potential livestock producers. Portions of population who are staying in rural areas have their predominat source of income from the agriculture sector including livestock subsector. This agricultural population becomes a good indicator as potential agricultural including livestock producer. For example, Indonesia, Vietnam, Myanmar, Thailand, and the Philippines are among member countries with higher portion of people working in agricultural sector, which is indicated by respective agricultural population. Agricultural population of the region also varies from only 1,000 people in Brunei to 2,000 people in Singapore as opposed to almost 50 million people in Indonesia. Table 3 further explains that agricultural population seems to be closely related to total population and total agricultural land in each country. Indonesia has the largest agricultural land of 56.5 million ha within the region compared to other ASEAN 
Table 1. Population of ASEAN member countries, 2006-2013 (000 people)

\begin{tabular}{|c|c|c|c|c|c|c|c|c|c|}
\hline Country & 2006 & 2007 & 2008 & 2009 & 2010 & 2011 & 2012 & 2013 & $(\%)$ \\
\hline Brunei & 365 & 370 & 375 & 380 & 387 & 393 & 400 & 406 & 1.6 \\
\hline Cambodia & 14,081 & 14,364 & 13,396 & 14,085 & 14,303 & 14,521 & 14,741 & 14,963 & 1.5 \\
\hline Indonesia & 222,747 & 225,642 & 228,523 & 231,370 & 237,641 & 241,991 & 245,425 & 248,818 & 1.4 \\
\hline Lao PDR & 5,747 & 5,873 & 6,000 & 6,128 & 6,256 & 6,385 & 6,514 & 6,644 & 2.0 \\
\hline Malaysia & 26,550 & 27,058 & 27,568 & 28,082 & 28,589 & 29,062 & 29,518 & 29,948 & 1.5 \\
\hline Myanmar & 56,515 & 57,504 & 58,377 & 59,130 & 59,780 & 60,384 & 60,976 & 61,568 & 1.2 \\
\hline Philippines & 86,973 & 88,575 & 90,457 & 92,227 & 94,013 & 95,804 & 97,594 & 99,385 & 1.8 \\
\hline Singapore & 4,401 & 4,589 & 4,839 & 4,988 & 5,077 & 5,184 & 5,312 & 5,399 & 1.6 \\
\hline Thailand & 65,574 & 66,041 & 66,482 & 66,903 & 67,313 & 67,597 & 67,911 & 68,251 & 0.5 \\
\hline Vietnam & 83,311 & 84,218 & 85,118 & 86,024 & 86,932 & 87,840 & 88,773 & 89,709 & 1.1 \\
\hline ASEAN & 566,263 & 574,233 & 581,136 & 589,317 & 600,291 & 609,161 & 617,165 & 625,091 & 1.3 \\
\hline
\end{tabular}

Source: ASEAN (2014)

Table 2. Urban population of ASEAN member countries, 1990-2013 (\%)

\begin{tabular}{lrrrrrrrr}
\hline \hline Country & 1990 & 2006 & 2007 & 2008 & 2010 & 2011 & 2012 & 2013 \\
\hline Brunei & n.a. & 73.6 & 74.4 & n.a. & 75.7 & 78.5 & 78.7 & n.a. \\
Cambodia & 12.6 & 20.0 & 17.8 & 17.9 & 19.9 & 21.0 & 21.5 & 21.4 \\
Indonesia & 30.6 & 43.1 & 43.1 & n.a. & 49.8 & 51.2 & 51.9 & 52.0 \\
Lao PDR & 18.1 & 21.0 & 29.7 & 29.7 & 33.2 & 35.0 & 35.3 & 36.0 \\
Malaysia & 50.7 & n.a. & 63.4 & 63.5 & 71.0 & 71.9 & 72.7 & 73.0 \\
Myanmar & 24.2 & 30.5 & 30.5 & 30.6 & 30.7 & 30.8 & 30.8 & 30.8 \\
Philippines & 48.8 & 63.0 & 63.5 & 64.2 & 66.4 & 48.5 & 48.6 & n.a. \\
Singapore & 100.0 & 100.0 & 100.0 & 100.0 & 100.0 & 100.0 & 100.0 & 100.0 \\
Thailand & 18.7 & 30.0 & 32.9 & 33.8 & 33.3 & 36.1 & 33.9 & n.a. \\
Vietnam & 19.7 & 27.7 & 28.2 & 29.0 & 30.5 & 31.6 & 31.9 & 32.3 \\
\hline ASEAN & 30.1 & 44.1 & 44.3 & n.a. & 43.6 & 44.2 & 44.7 & n.a. \\
\hline
\end{tabular}

n.a.: not available

Source: ASEAN (2014)

member countries. Following Indonesia are Thailand with 21.9 million ha, Myanmar 12.6 million ha, the Philippines 12.4 million ha. However, proportionally Thailand has $43 \%$ of its total land area used for agricultural purposes, followed by the Philippines $41.6 \%$, Vietnam 35\%, Cambodia 33\%, and Indonesia $31 \%$.

Furthermore, Table 4 presented some indices such as GDP share, employment share, export and import share. In terms of GDP share of agricultural sector it is obvious that in 2012 Myanmar has the largest share of $35 \%$ followed by Lao PDR 27\%, Cambodia $25 \%$, and Vietnam $16 \%$. Table 4 also presents the GDP share of Agriculture in the region which varies from $1 \%$ for Brunei to $35 \%$ for Myanmar. Indonesia and the Philippines have relatively high employment share of agricultural sector which were around 35\%. Meanwhile, Myanmar, Lao PDR, Thailand, Vietnam and Indonesia are member countries with higher import share of agricultural sector compared to the rest of countries. It is also obvious that in 2013 the export shares of agricultural sector in those countries were almost twice larger than the import share. Employment share of agricultural sector in 2013 was sequentially presented for Thailand $36 \%$, Indonesia $35 \%$, Malaysia $13 \%$, except for some countries for which data were unavailable. Import share of agricultural sector can also be anticipated using information presented in Table 3 on the percentage of agricultural land in respective countries. For example, in terms of import share of agricultural sector Brunei has the largest share by $15 \%$ followed by the Philippines $11 \%$, while other member countries such as Indonesia, Malaysia, Myanmar, and Vietnam have 
almost similar share around $8 \%$. On the other hand, Myanmar apparently has the largest export share of agricultural sector by $30 \%$, followed by Lao PDR $21 \%$, Thailand $13.5 \%$, Vietnam $12 \%$, the Philippines $11 \%$, and Malaysia $11 \%$.

As it is expected, Singapore and Brunei apparently have the largest GDP per capita among member countries ranging from USD 40,000-55,000, leaving Cambodia, Myanmar, and Vietnam at their level of only USD 800-2,000, and Indonesia was slightly higher at USD 3,460. Most countries had decreased GDP per capita in 2009, except Indonesia, Lao PDR, Vietnam, and Myanmar, but it recovered and increased again starting from 2010. Table 5 further indicates that only Singapore, Brunei, Malaysia, and Thailand are countries with higher GDP per capita above average in the region. This also implies that the demand for livestock products in these countries is expected to be far beyond the rest of the member countries. From the data presented in Table 3 and 4, it is obvious that Brunei with high GDP per capita also has high import share of agricultural sector. However,

Table 3. Land use in ASEAN member countries, 2012 (000 ha)

\begin{tabular}{|c|c|c|c|c|c|c|c|c|}
\hline \multirow{3}{*}{ Country } & \multirow{3}{*}{ Total area } & \multicolumn{7}{|c|}{ Land area } \\
\hline & & \multirow{2}{*}{$\begin{array}{l}\text { Total land } \\
\text { area }\end{array}$} & \multicolumn{6}{|c|}{ Agricultural area } \\
\hline & & & $\begin{array}{c}\text { Arable } \\
\text { land }\end{array}$ & $\begin{array}{l}\text { Permanent } \\
\text { crops }\end{array}$ & $\begin{array}{l}\text { Permanent } \\
\text { pasture }\end{array}$ & $\begin{array}{c}\text { Total agric } \\
(4+5+6)\end{array}$ & $\begin{array}{c}\% \text { to land } \\
\text { area }\end{array}$ & $\begin{array}{c}\text { Agric pop } \\
(000)\end{array}$ \\
\hline (1) & (2) & (3) & (4) & $(5)$ & (6) & (7) & (8) & (9) \\
\hline Brunei & 577 & 527 & 4 & 6 & 3 & 13 & 2.5 & 1 \\
\hline Cambodia & 18,104 & 17,652 & 4,100 & 155 & 1,500 & 5,755 & 32.6 & 5,226 \\
\hline Indonesia & 191,093 & 181,157 & 23,500 & 22,000 & 11,000 & 56,500 & 31.2 & 49,963 \\
\hline Lao PDR & 23,680 & 23,080 & 1,450 & 169 & 850 & 2,469 & 10.7 & 2,586 \\
\hline Malaysia & 33,080 & 32,855 & 965 & 6,500 & 285 & 7,750 & 23.6 & 1,513 \\
\hline Myanmar & 67,659 & 65,329 & 10,820 & 1,465 & 308 & 12,593 & 19.3 & 20,726 \\
\hline Philippines & 30,000 & 29,817 & 5,545 & 5,350 & 1,500 & 12,395 & 41.6 & 13,571 \\
\hline Singapore & 72 & 70 & 1 & 0 & n.a. & 1 & 1.0 & 2 \\
\hline Thailand & 51,312 & 51,089 & 16,650 & 4,500 & 800 & 21,860 & 42.8 & 18,032 \\
\hline Vietnam & 33,095 & 31,007 & 6,400 & 3,800 & 642 & 10,842 & 35.0 & 30,566 \\
\hline ASEAN & 448,672 & 432,583 & 69,344 & 43,945 & 16,888 & 130,178 & 30.1 & 142,186 \\
\hline
\end{tabular}

n.a.: not available

Source: ASEAN (2014)

Table 4. GDP share, employment, export and import share of agricultural sector of ASEAN member countries, $2012-2013$ (\%)

\begin{tabular}{|c|c|c|c|c|c|c|c|c|}
\hline \multirow{2}{*}{ Country } & \multicolumn{2}{|c|}{ GDP Share } & \multicolumn{2}{|c|}{ Employment Share } & \multicolumn{2}{|c|}{ Export Share } & \multicolumn{2}{|c|}{ Import Share } \\
\hline & 2012 & 2013 & 2012 & 2013 & 2012 & 2013 & 2012 & 2013 \\
\hline Brunei & 1.3 & 1.3 & n.a. & n.a. & 0.05 & 0.16 & 11.95 & 15.17 \\
\hline Cambodia & 25.0 & n.a. & n.a. & n.a. & 3.00 & 4.52 & 6.95 & 6.25 \\
\hline Indonesia & 12.5 & 12.3 & 35.1 & 34.8 & 17.13 & 17.04 & 8.55 & 8.97 \\
\hline Lao PDR & 26.9 & n.a. & n.a. & n.a. & 18.77 & 21.14 & 6.68 & 4.98 \\
\hline Malaysia & 7.3 & 7.2 & 12.6 & 12.7 & 12.02 & 10.54 & 8.50 & 7.67 \\
\hline Myanmar & 34.9 & n.a. & n.a. & n.a. & 35.35 & 29.60 & 8.53 & 8.54 \\
\hline Philippines & 11.1 & 10.4 & 32.2 & n.a. & 9.27 & 10.92 & 10.94 & 10.82 \\
\hline Singapore & 0.0 & 0.0 & n.a. & n.a. & 2.21 & 2.41 & 3.37 & 3.55 \\
\hline Thailand & 8.4 & 8.3 & 38.9 & 36.2 & 14.02 & 13.50 & 5.23 & 5.27 \\
\hline Vietnam & 15.8 & 17.6 & 48.4 & n.a. & 14.59 & 12.24 & 8.05 & 7.98 \\
\hline
\end{tabular}

n.a.: not available

Source: ASEAN (2014) 
Malaysia and Thailand with high GDP per capita have less import share meaning that these two countries have been able to manage their demands for livestock products domestically.

Jabbar (2015) reviewed the ASEAN Economic Community (AEC) blueprint which envisages that cooperation in food, agriculture and forestry is one of the seven key elements or approaches to create ASEAN as a single market and production base. Within agriculture, livestock sub-sector plays a key role in growth, employment, trade, food and nutrition security, poverty alleviation and gender equality. Share of agriculture in GDP usually declines with economic development but within agriculture share of livestock tends to increase due to changes in demand and dietary pattern towards protein rich foods. The same kind of changes is taking place in various degrees in ASEAN member states because of different levels of their development.

Furthermore, Faizaty (2014) underlined that GDP of an exporter country measures the production capacity of the country, while GDP of an importer country measures capacity to absorb by the country. In addition, country's national income in terms of GDP or per capita income, as well as the GDP sum of the trading partners also influence the trading between the countries. Other important factors include human population, exchange rate, distance as a proxy of transportation costs, import tariff, and trade cooperation. So far Singapore, Malaysia and Thailand have enjoyed the regional market under AEC, while Indonesia has not yet been as that beneficial compared to those countries. Consequently, Indonesia has to improve some of the livestock and poultry production parameters to reduce production costs in order to achieve a better competition status.

The region has total agriculture land of 130 million hectares or about $31 \%$ of the total land available in the area and the region varies in its livestock and poultry population. Within the region, Indonesia evidently leads on the population of beef by 16.6 million heads, sheep 14.5 million heads, goats 18.6 million heads, and chickens 1,793 million heads. Vietnam and the Philippines lead in pigs population by 26.2 million heads and 11.8 million heads respectively, and these figures show similar pattern for meat production in the respective countries. Moreover, the population figures grew positively from 2010-2013 in all member countries with exemption for buffalo, chicken in Cambodia, and sheep-goats in all countries except in Indonesia, Lao and Myanmar. Beef cattle population was very minimal in both Brunei and Singapore, but moderately found in Malaysia, Lao PDR, the Philippines, and Cambodia. Indonesia, Thailand and Vietnam are member countries which were considered to have reasonably high beef cattle population. Finally, pig population was significantly shown by Vietnam, the Philippines, Indonesia and Thailand.

Note that Indonesia was the only country in the region which has significant sheep population compared to the rest of the member countries. Similarly, goats population was predominantly found in Indonesia, the Philippines and Vietnam. Indonesia is also leading in chicken population in the region, while Malaysia, Thailand, Vietnam, and the Philippines have almost similar number of chicken population (Table 6).

Table 5. GDP per capita at current prices, 2006-2013 (USD)

\begin{tabular}{lrrrrrrrr}
\hline \hline Country & \multicolumn{1}{c}{2006} & \multicolumn{1}{c}{2007} & \multicolumn{1}{c}{2008} & \multicolumn{1}{c}{2009} & \multicolumn{1}{c}{2010} & \multicolumn{1}{c}{2011} & \multicolumn{1}{c}{2012} & 2013 \\
\hline Brunei & 31,452 & 33,191 & 38,621 & 28,454 & 32,063 & 42,431 & 42,445 & 39,679 \\
Cambodia & 515 & 601 & 827 & 735 & 785 & 882 & 950 & 1,037 \\
Indonesia & 1,636 & 1,910 & 2,244 & 2,359 & 2,988 & 3,498 & 3,563 & 3,460 \\
Lao PDR & 576 & 719 & 882 & 913 & 1,079 & 1,262 & 1,443 & 1,548 \\
Malaysia & 6,160 & 7,166 & 8,393 & 7,216 & 8,515 & 9,962 & 10,346 & 10,420 \\
Myanmar & 233 & 333 & 436 & 538 & 706 & 853 & 885 & 888 \\
Philippines & 1,408 & 1,717 & 1,917 & 1,829 & 2,127 & 2,339 & 2,568 & 2,707 \\
Singapore & 33,580 & 39,224 & 39,724 & 38,577 & 46,570 & 52,865 & 54,007 & 55,182 \\
Thailand & 3,162 & 3,743 & 4,106 & 3,947 & 4,743 & 5,116 & 5,391 & 5,679 \\
Vietnam & 798 & 918 & 1,165 & 1,232 & 1,338 & 1,543 & 1,755 & 1,909 \\
\hline ASEAN & 1,955 & 2,309 & 2,647 & 2,610 & 3,162 & 3,619 & 3,781 & 3,832 \\
\hline
\end{tabular}

Source: ASEAN (2014) 
Otte (2014) agreed that heterogeneity prevails in ASEAN member countries are rather diverse in many aspects and large disparities exist in population sizes, cultural backgrounds, structure and development of the economies, and levels of disposable income. Likewise, large differences exist in the structure of the livestock sectors of members and their respective levels of technology adoption. Livestock and poultry meat production in the region may also be a reflection of the level of technology adoption in each member country (Table 7).

It is interesting to know how these livestock and poultry sectors performed in each ASEAN member countries, and which species is performing better than the other within the country and between countries. Assessment of these sectors focused only on four groups of meat producing species, namely beef, pigs, sheep and goats, and broiler since these animals species are considered as major meat producer and showed their positive growth during the period of 2010-2013. Producer's price of live weight of each species measured by USD/ton was used as a measure, because it is a good proxy to measure the production cost, as one of elements of competition in producing livestock and poultry in the region. Therefore, the least the production cost of a livestock species among member countries, the more competitive status of the respective country.

Table 8 presents different production costs of live beef cattle in eight member countries. It indicates that in 2013 Cambodia was the most competitive country to produce per $\mathrm{kg}$ live beef cattle at USD 1.97, followed by the Philippines USD 2.06, Malaysia USD 3.27, and Indonesia USD 3.34. However, Indonesia at its rank $4^{\text {th }}$ still has a good potency to produce competitive live beef cattle through its current national program to accelerate palm oil-beef cattle integration system. Technologies and innovations to implement the integrated oil palm-ruminants are already made available national wide as a way to achieve better production efficiency for both enterprises, the oil palm estate and the ruminant productions. Research and development in the integrated oil-palm and beef cattle system have been carried out in Indonesia particularly in the island of Sumatera and Kalimantan since 2003 where the fast majority of oil-palm plantation takes place, and shows very promising results in terms of reducing production cost and increasing beef cattle population (Sudaryanto 2017).

In addition to that, recently there has been effort to also integrate sheep with oil palm estate; hence, these ruminant productions are expected to be more efficient in the future. Feed technology to optimize the use oil palm leaves and fronds along with its factory by products as ruminants feed has also been introduced to some oil palm enterprises with good prospect and promising results. The series of research done in this area has proved evidently that for each one hectare of oil palm plantation, there is biomass available as feeds for one mature cattle.

As far as beef cattle production is concerned, with current Indonesia's national program to accelerate beef production through oil-palm-beef cattle integrated system, the program will, in the near future, change the country's position in producing beef cattle which is currently at $4^{\text {th }}$ rank within ASEAN member countries. According to DGEC (2015) data, given current 11 million hectares of oil-palm plantation area, with potential stocking rate of 1.5 to 2 heads of mature cattle per hectare (Mathius 2008; 2009), there is a potential for additional two million mature cattle population for this country. This will provide additional live cattle supply as mature-ready to slaughter cattle and, hence, will reduce the production cost of feeder stocks (Soedjana \& Diwyanto 2014).

In relation to the good potential opportunity from the integrated system for oil palm and ruminants production, Indonesia has significant sheep population compared to the rest of the member countries, while goat population was predominantly found in Indonesia, the Philippines, and Vietnam. However, the most competitive country to produce live sheep and goats were not related to population as a measure. Moreover, Table 9 showed that in 2013 the Philippines can be considered as the most competitive country with cost of sheep and goat production per kg live weight of USD 2.52, followed by Vietnam USD 4.06, Indonesia USD 5.62, and Malaysia USD 6.67. However, Indonesia being a country with the highest population of sheep and goats in the region has not yet been able to produce sheep and goats competitively compared to other countries with lower population, such as the Philippines and Vietnam.

Although a reasonably high pig population showed by Vietnam, the Philippines, Indonesia and Thailand, Table 10 indicates that the production costs to produce per $\mathrm{kg}$ live pig in 2013 was competitively showed by Malaysia at USD 1.91, Vietnam USD 1.97 and Thailand USD 2.13. Only Vietnam and Thailand were the two countries which almost consistently in their performance on both population and production cost, while Indonesia and the Philippines were only in the order of rank $5^{\text {th }}$ and $4^{\text {th }}$ in the order of least production costs.

Similarly for chicken sector, Indonesia with the highest chicken population and only at rank $4^{\text {th }}$ in the region, compared to Thailand, Malaysia, and the Philippines, has not yet performed well in terms of production costs. Thailand, however, as presented in Table 11 can be considered as the most competitive 
Table 6. Livestock and poultry population, 2010-2013 (000 head)

\begin{tabular}{|c|c|c|c|c|c|c|c|c|c|c|c|c|c|c|c|c|}
\hline \multirow{2}{*}{ Country } & \multicolumn{4}{|c|}{2010} & \multicolumn{4}{|c|}{2011} & \multicolumn{4}{|c|}{2012} & \multicolumn{4}{|c|}{2013} \\
\hline & $\mathrm{C}+\mathrm{B}$ & Pig & $\mathrm{S}+\mathrm{H}$ & $\mathrm{C}+\mathrm{D}$ & $\mathrm{C}+\mathrm{B}$ & Pig & $\mathrm{S}+\mathrm{H}$ & $\mathrm{C}+\mathrm{D}$ & $\mathrm{C}+\mathrm{B}$ & Pig & $\mathrm{S}+\mathrm{H}$ & $\mathrm{C}+\mathrm{D}$ & $\mathrm{C}+\mathrm{B}$ & Pig & $\mathrm{S}+\mathrm{H}$ & $\mathrm{C}+\mathrm{D}$ \\
\hline Brunei & 5.0 & 1.3 & 10.6 & 15,130 & 5.0 & 1.3 & 11.0 & 15,225 & 5.1 & 1.3 & 11.2 & 15,728 & 3.2 & 1.2 & 11.0 & 19,230 \\
\hline Cambodia & 4,187 & 2,057 & - & 24,948 & 4,109 & 2,000 & - & 25,000 & 3,595 & 2,120 & - & 22,647 & 3,576 & 2,150 & - & 21,300 \\
\hline Indonesia & 15,587 & 7,477 & 27,345 & $1,393,932$ & 16,129 & 7,758 & 28,885 & $1,476,552$ & 17,413 & 7,831 & 30,626 & $1,597,121$ & 18,081 & 8,246 & 33,136 & $1,843,953$ \\
\hline Lao PDR & 2,660 & 2,752 & 367.0 & 28,305 & 2,706 & 7,758 & 431.0 & 30,350 & 2,880 & 2,794 & 444.0 & 32,179 & 2,880 & 2,800 & 450.0 & 33,450 \\
\hline Malaysia & 1,040 & 1,711 & 666.0 & 152,989 & 1,055 & 1,695 & 670.0 & 278,900 & 908.0 & 1,799 & 630.0 & 301,778 & 870.0 & 1,817 & 612.0 & 319,243 \\
\hline Myanmar & 16,061 & 8,496 & 4,085 & 152,989 & 16,587 & 9,416 & 4,200 & 170,907 & 17,700 & 10,500 & 4,760 & 196,000 & 17,600 & 10,530 & 4,792 & 206,100 \\
\hline Singapore & 0.2 & 270 & 0.7 & 4,050 & 0.2 & 270.0 & 0.7 & 4,050 & 0.2 & 272.0 & 0.7 & 4,255 & 0.2 & 272 & 0.7 & 4,250 \\
\hline Thailand & 8,121 & 7,624 & 423.0 & 261,151 & 8,378 & 7,660 & 480.0 & 267,179 & 6,935 & 7,500 & 504.0 & 281,202 & 6,435 & 7,924 & 462 & 283,242 \\
\hline Vietnam & 8,685 & 27,373 & 1,288 & 286,864 & 8,149 & 27,056 & 1,268 & 322,600 & 7,817 & 26,494 & 1,344 & 308,461 & 7,706 & 26,261 & 1,345 & 314,756 \\
\hline ASEAN & 62,187 & 71,159 & 38,383 & $2,595,451$ & 62,706 & 71,124 & 39,816 & $2,748,477$ & 62,709 & 71,173 & 42,057 & $2,933,574$ & 62,580 & 71,843 & 44,523 & $3,209,815$ \\
\hline
\end{tabular}

C+B: Cattle and buffalo; S+H: Sheep and goat; C+D: Chicken and duck

Source: ASEAN (2014)

Table 7. Livestock and poultry meat production by ASEAN countries, 2010-2013 (000 tons)

\begin{tabular}{|c|c|c|c|c|c|c|c|c|c|c|c|c|c|c|c|c|}
\hline \multirow{2}{*}{ Country } & \multicolumn{4}{|c|}{2013} & \multicolumn{4}{|c|}{2012} & \multicolumn{4}{|c|}{2011} & \multicolumn{4}{|c|}{2010} \\
\hline & A & B & $\mathrm{C}$ & D & A & B & $\mathrm{C}$ & D & A & B & $\mathrm{C}$ & D & A & B & $\mathrm{C}$ & $\mathrm{D}$ \\
\hline Brunei & 0.8 & 0.0 & 0.1 & 26.9 & 0.8 & 0.1 & 0.1 & 19.7 & 0.8 & 0.1 & 0.1 & 19.4 & 0.8 & 0.1 & 0.1 & 18.8 \\
\hline Cambodia & 73.2 & 98.5 & n.a. & 26.7 & 73.4 & 98.5 & n.a. & 28.0 & 72.9 & 97.5 & n.a. & 28.0 & 72.7 & 100.0 & n.a. & 28.2 \\
\hline Indonesia & 585.9 & 742.5 & 112.7 & $1,872.5$ & 540.8 & 728.8 & 115.1 & $1,781.0$ & 503.3 & 721.1 & 121.2 & $1,642.8$ & 472.4 & 695.0 & 113.7 & $1,565.6$ \\
\hline Lao PDR & 48.2 & 64.0 & 1.7 & 25.3 & 47.6 & 62.0 & 1.7 & 25.3 & 46.0 & 64.0 & 1.7 & 24.8 & 45.2 & 59.4 & 1.4 & 24.0 \\
\hline Malaysia & 30.6 & 231.4 & 2.1 & $1,359.9$ & 30.3 & 235.6 & 2.1 & $1,323.6$ & 29.8 & 231.3 & 0.8 & $1,427.6$ & 28.9 & 234.0 & 0.9 & $1,404.6$ \\
\hline Philippines & 296.9 & $1,681.1$ & 54.7 & $1,079.1$ & 296.9 & $1,677.5$ & 53.1 & 979.4 & 302.9 & $1,649.3$ & 50.9 & 807.7 & 299.2 & $1,613.5$ & 52.1 & 773.0 \\
\hline Singapore & 0.1 & 19.6 & 0.04 & 97.1 & 0.1 & 19.6 & 0.04 & 97.1 & n.a. & 19 & n.a. & 95.1 & 0 & 18.8 & n.a. & 94.5 \\
\hline Thailand & 194.7 & 967.3 & 1.9 & $1,469.8$ & 203.2 & 886.3 & 1.7 & $1,348.3$ & 193.2 & 867.3 & 1.9 & $1,340.2$ & 222.9 & 862 & 1.7 & 1,301 \\
\hline Vietnam & 379.1 & $3,217.9$ & 8.1 & 633 & 393.3 & 3,160 & 8.1 & 617.9 & 386.5 & $3,098.9$ & 8.1 & 617 & 384.3 & $3,036.4$ & 8.2 & 531.4 \\
\hline
\end{tabular}

Livestock data for Myanmar were not available; n.a.: not available; A: Beef; B: Pig meat; C: Mutton \& goat; D: Poultry meat

Source: ASEAN (2014) 
Table 8. Production cost for live beef cattle in ASEAN member countries (USD/kg)

\begin{tabular}{ccccccccc}
\hline \hline & \multicolumn{7}{c}{ Country (rank) } \\
\cline { 2 - 10 } & $\begin{array}{c}\text { Brunei } \\
(8)\end{array}$ & $\begin{array}{c}\text { Cambodia } \\
(1)\end{array}$ & $\begin{array}{c}\text { Indonesia } \\
(4)\end{array}$ & $\begin{array}{c}\text { Lao PDR } \\
(7)\end{array}$ & $\begin{array}{c}\text { Malaysia } \\
(3)\end{array}$ & $\begin{array}{c}\text { Philippines } \\
(2)\end{array}$ & $\begin{array}{c}\text { Thailand } \\
(6)\end{array}$ & $\begin{array}{c}\text { Vietnam } \\
(5)\end{array}$ \\
\hline 2006 & n.a. & 1.16 & 2.46 & 1.60 & 1.78 & 1.30 & 2.92 & 109 \\
2007 & 7.10 & 1.31 & 2.73 & 2.12 & 2.04 & 1.44 & 2.79 & 1.26 \\
2008 & 8.27 & 1.64 & 2.38 & 2.80 & 2.12 & 1.65 & 2.45 & 2.14 \\
2009 & 8.17 & 1.57 & 2.71 & 3.36 & 2.12 & 1.62 & 2.35 & 2.26 \\
2010 & 8.64 & 1.63 & 3.30 & 3.97 & 2.44 & 1.81 & 2.54 & 2.48 \\
2011 & 9.75 & 1.90 & 3.52 & 4.59 & 2.68 & 1.93 & 3.02 & 2.72 \\
2012 & 10.16 & 1.95 & 3.44 & 5.33 & 3.07 & 1.99 & 3.45 & 3.36 \\
2013 & 10.47 & 1.97 & 3.34 & 5.20 & 3.27 & 2.06 & 4.25 & 3.80 \\
\hline
\end{tabular}

Data for Myanmar and Singapore were not available; n.a.: not available

Source: FAOSTAT (2015), adapted from USD/ton to USD/kg

Table 9. Production cost for live sheep and goats in ASEAN member countries (USD/kg)

\begin{tabular}{lccccc}
\hline & \multicolumn{3}{c}{ Country (rank) } \\
\cline { 2 - 6 } Year & $\begin{array}{c}\text { Brunei } \\
(5)\end{array}$ & $\begin{array}{c}\text { Indonesia } \\
(3)\end{array}$ & $\begin{array}{c}\text { Malaysia } \\
(4)\end{array}$ & $\begin{array}{c}\text { Philippines } \\
(1)\end{array}$ & $\begin{array}{c}\text { Vietnam } \\
(2)\end{array}$ \\
\hline 2006 & n.a. & 5.45 & 3.47 & 1.36 & 1.95 \\
2007 & 11.60 & 6.12 & 4.04 & 1.52 & 1.79 \\
2008 & 12.95 & 6.52 & 4.55 & 1.70 & 2.84 \\
2009 & 12.78 & 7.37 & 4.24 & 2.07 & 2.31 \\
2010 & 13.53 & 9.37 & 5.06 & 2.28 & 2.42 \\
2011 & 15.27 & 6.64 & 5.56 & 2.41 & 2.91 \\
2012 & 15.91 & 6.54 & 5.75 & 2.52 & 3.50 \\
2013 & 16.39 & 5.62 & 6.67 & & 4.06 \\
\hline
\end{tabular}

Data for five other member countries were not available; n.a.: not available

Source: FAOSTAT (2015), adapted from USD/ton to USD/kg

country to produce per $\mathrm{kg}$ live chicken at USD 1.41, followed by Malaysia USD 1.51, the Philippines USD 2.06, and Indonesia USD 3.30.

Table 12 summarizes performances of each member country in terms of human population along with their urban population and agricultural population, agricultural GDP share and ranks of their competitiveness on beef cattle, sheep and goats, broilers, and pigs in terms of production cost. Indonesia with the highest human population and also the highest population of beef cattle, sheep and goats, and chickens has not yet reached rank $1^{\text {st }}$ nor $2^{\text {nd }}$ for the production cost of the four livestock commodities. They are only at rank $4^{\text {th }}$ for beef cattle, rank $3^{\text {rd }}$ for sheep and goats, rank $4^{\text {th }}$ for chickens, and rank $5^{\text {th }}$ for pigs. The following member countries are at their first rank or competitiveness status for the four livestock commodities, namely Cambodia for beef cattle, Malaysia for pigs, the Philippines for sheep and goats, and Thailand for broiler chickens (Figure 1).

Because animal husbandry in Indonesia is dominated by traditional and small scale, located mostly in rural areas, the policy option aimed at increasing production and productivity of livestock production should include the role and functions of livestock farming systems prevail in the rural areas (Soedjana 2011). However, most of small scale operations continue to face limits to intensification, although few have managed to upscale or specialize to a point where they can advance economically, and many depend partly on off-farm employment for their food security. 
Table 10. Production cost for live pigs in ASEAN member countries (USD/kg)

\begin{tabular}{cccccccc}
\hline \hline & \multicolumn{7}{c}{ Country (rank) } \\
\cline { 2 - 8 } Year & $\begin{array}{c}\text { Cambodia } \\
(7)\end{array}$ & $\begin{array}{c}\text { Indonesia } \\
(5)\end{array}$ & $\begin{array}{c}\text { Lao PDR } \\
(6)\end{array}$ & $\begin{array}{c}\text { Malaysia } \\
(1)\end{array}$ & $\begin{array}{c}\text { Philippines } \\
(4)\end{array}$ & $\begin{array}{c}\text { Thailand } \\
(3)\end{array}$ & $\begin{array}{c}\text { Vietnam } \\
(2)\end{array}$ \\
\hline 2006 & 4.17 & 1.35 & 1.36 & 1.67 & 1.35 & 1.24 & 1.05 \\
2007 & 4.50 & 1.41 & 1.65 & 1.38 & 1.55 & 1.11 & 1.18 \\
2008 & 5.63 & 1.66 & 2.05 & 1.92 & 1.85 & 1.60 & 1.81 \\
2009 & 5.38 & 1.73 & 2.35 & 1.96 & 1.79 & 1.66 & 1.67 \\
2010 & 5.59 & 2.10 & 2.68 & 2.43 & 2.01 & 1.89 & 1.57 \\
2011 & 6.51 & 2.78 & 3.01 & 2.48 & 2.06 & 2.15 & 2.25 \\
2012 & 6.70 & 2.66 & 3.76 & 2.07 & 2.09 & 1.82 & 2.09 \\
2013 & 6.77 & 2.43 & 2.96 & 1.91 & 2.26 & 2.13 & 1.97 \\
\hline
\end{tabular}

Data for Brunei, Myanmar, and Singapore were not available

Source: FAOSTAT (2015), adapted from USD/ton to USD/kg

Table 11. Production cost for live bird broiler in ASEAN member countries (USD/kg)

\begin{tabular}{|c|c|c|c|c|c|c|c|c|}
\hline \multirow[b]{2}{*}{ Year } & \multicolumn{8}{|c|}{ Country (rank) } \\
\hline & $\begin{array}{l}\text { Brunei } \\
\text { (5) }\end{array}$ & $\begin{array}{c}\text { Cambodia } \\
\text { (7) }\end{array}$ & $\begin{array}{c}\text { Indonesia } \\
\text { (4) }\end{array}$ & $\begin{array}{l}\text { Lao PDR } \\
\text { (6) }\end{array}$ & $\begin{array}{c}\text { Malaysia } \\
\text { (2) }\end{array}$ & $\begin{array}{l}\text { Philippines } \\
\text { (3) }\end{array}$ & $\begin{array}{l}\text { Thailand } \\
\text { (1) }\end{array}$ & $\begin{array}{c}\text { Vietnam } \\
\text { (8) }\end{array}$ \\
\hline 2006 & 2.58 & 3.75 & 2.46 & 1.64 & 0.97 & 1.41 & 0.83 & 1.80 \\
\hline 2007 & 2.76 & 4.32 & 2.61 & 1.99 & 1.09 & 1.75 & 0.98 & 2.93 \\
\hline 2008 & 2.92 & 3.52 & 3.13 & 2.48 & 1.24 & 1.79 & 1.12 & 3.51 \\
\hline 2009 & 2.88 & 3.24 & 3.69 & 2.84 & 1.15 & 1.88 & 1.11 & 3.77 \\
\hline 2010 & 3.05 & 3.38 & 4.49 & 3.23 & 1.32 & 2.09 & 1.35 & 3.74 \\
\hline 2011 & 3.44 & 3.76 & 4.03 & 3.63 & 1.55 & 2.19 & 1.54 & 4.19 \\
\hline 2012 & 3.59 & 3.93 & 3.85 & 4.31 & 1.42 & 2.27 & 1.35 & 4.23 \\
\hline 2013 & 3.70 & 3.97 & 3.30 & 3.96 & 1.51 & 2.06 & 1.41 & 4.52 \\
\hline
\end{tabular}

Data for Myanmar and Singapore were not available

Source: FAOSTAT (2015), adapted from USD/ton to USD/kg

Moreover, beef is also known as high income elastic commodity prevails in Indonesia, with income elasticity of demand of $1.64 \%$ (Kustiari et al. 2010) meaning that for every $1 \%$ increase in income of the consumers the household will spend $1.64 \%$ of its income to purchase beef. This implies that the demand for beef will continue to increase as per capita income rises mostly from urban households, and the economy grows. However, domestic beef production has been managed by almost $97 \%$ by the smallholder farmers who keep only 1 to 3 cattle per household. They utilize traditional techniques, keep their animals as a live saving and market them anytime when cash are needed (Soedjana 2013a), and this potentially creates higher production cost per kilogram of live weight of beef cattle.
Soedjana (2013b) found out that diversified food consumption of animal origin in Indonesia has been naturally established. Livestock meat consumption diversification is based on many reasons including cultural, preferences or other economic status or income of the households. This phenomenon is also indicated by the magnitude of positive cross price elasticity between beef and mutton, beef and poultry meat, and between poultry meat and fish. Therefore, every effort to push higher consumption of one meat type will reduce the participation rate of others. Participation rates for beef and buffalo meats were found to be $26.15 \%$ (2002), $21.93 \%$ (2005), $16.18 \%$ (2008), 16.16\% (2011), and 15.52\% (2014). These data implied that increase demand for beef was mainly due 
Table 12. Summary of important indices for ASEAN member countries

\begin{tabular}{|c|c|c|c|c|c|c|c|c|c|}
\hline \multirow{2}{*}{ Country } & \multirow{2}{*}{$\begin{array}{l}\text { Human } \\
\text { population } \\
(000)\end{array}$} & \multirow{2}{*}{$\begin{array}{c}\text { Urban } \\
\text { population } \\
(\%)\end{array}$} & \multirow{2}{*}{$\begin{array}{l}\text { Agriculture } \\
\text { population } \\
(000)\end{array}$} & \multirow{2}{*}{$\begin{array}{l}\text { Agric. } \\
\text { GDP share } \\
(\%)\end{array}$} & \multirow{2}{*}{$\begin{array}{c}\text { GDP per } \\
\text { capita } \\
\text { (USD) }\end{array}$} & \multicolumn{4}{|c|}{$\begin{array}{l}\text { Rank of competitiveness based on } \\
\text { production cost (USD/ton) }\end{array}$} \\
\hline & & & & & & Beef & Sheep \& Goats & Broiler & Pigs \\
\hline Brunei & 406 & 78.0 & 1 & 1.3 & 39,679 & 8 & 5 & 5 & n.a. \\
\hline Cambodia & 14,963 & 21.5 & 5,226 & 25.0 & 1,037 & 1 & n.a. & 7 & 7 \\
\hline Indonesia & 248,818 & 52.0 & 49,963 & 12.3 & 3,460 & 4 & 3 & 4 & 5 \\
\hline Lao PDR & 6,644 & 36.0 & 2,586 & 26.9 & 1,548 & 7 & n.a. & 6 & 6 \\
\hline Malaysia & 29,948 & 73.0 & 1,513 & 7.2 & 10,420 & 3 & 4 & 2 & 1 \\
\hline Philippines & 99,385 & 48.6 & 13,571 & 10.4 & 2,707 & 2 & 1 & 3 & 4 \\
\hline Singapore & 5,399 & 100.0 & 2 & 0.0 & 55,182 & n.a. & n.a. & n.a. & n.a. \\
\hline Thailand & 68,251 & 34.0 & 18,032 & 8.3 & 5,679 & 6 & n.a. & 1 & 3 \\
\hline Vietnam & 89,709 & 32.2 & 30,566 & 17.6 & 1,909 & 5 & 2 & 8 & 2 \\
\hline
\end{tabular}

Livestock data for Myanmar were not available; n.a.: not available

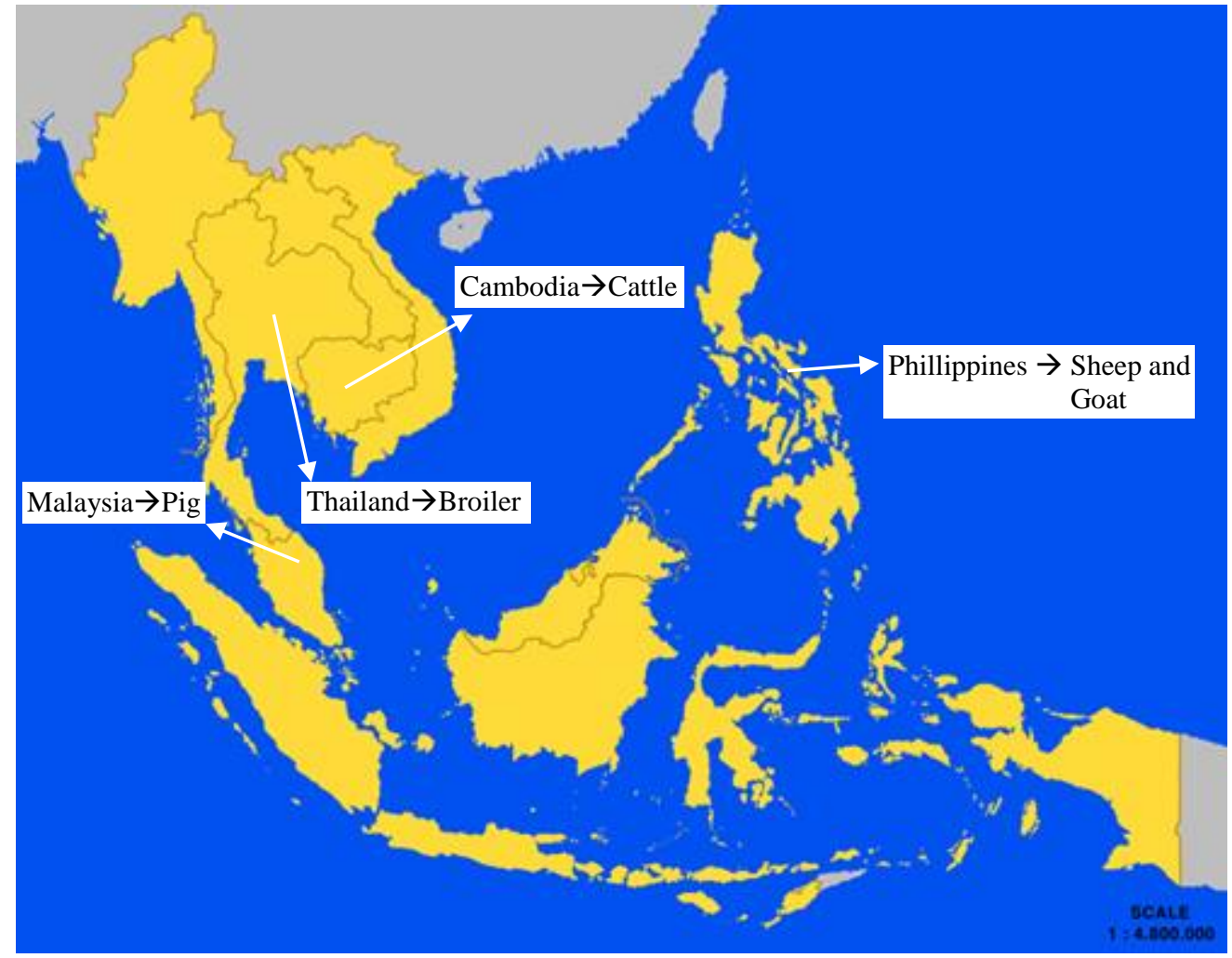

Figure 1. The highest rank of competitiveness of ASEAN countries based on production cost of livestock 
to increased number of middle and upper income household within the population.

Table 12 indicates that the Philippines (sheepgoats, beef, pigs, and broilers), Malaysia (broilers, pigs, beef, and sheep-goats), Thailand (broilers and pigs), Vietnam (sheep-goats and pigs) and Indonesia (sheepgoats, beef, and broilers) have bright opportunities for improving the red and white meat production and productivities to achieve upper level of competitiveness in terms of low livestock and poultry production cost. These five member countries indicate their good level of competitiveness in terms of cost of producing live beef, sheep and goats, pigs, and broilers.

Since broiler and pig productions are mostly run by large corporation, it seems that competitive elements of these two subsectors have to do with the government policy and incentive systems, such as low interest, infrastructure, and other facilities for export promotion to improve the production system in order to compete with other poultry and pigs producing countries in the region, such as Thailand and Malaysia which are considered as countries with poultry meat and eggs self sufficiency ratio above $100 \%$ (Orissa International 2017).

\section{STRATEGY TO IMPROVE INDONESIA COMPETITIVENESS}

Livestock subsector in Indonesia, as in many other developing countries, plays a significant role particularly for rural livelihoods and the economy of the country. They are a crucial asset for the poor, and provide an important source of nutritive food for both rural and urban households. These socio-economic roles and others are increasing in their importance as the sector grows because of increasing human populations, incomes, and urbanization rates. In order to provide these benefits, the subsector uses a significant amount of land, biomass, and other resources. There is concern, however, on how to manage the sector's growth, so that these benefits can be attained at a lower environmental cost, despite the fact that manures from ruminant systems can be a valuable source of fertilizer for smallholder crops. Because of the high yield gaps in most of these production systems, increasing the efficiency of the livestock sector through sustainable intensification practices presents a real opportunity where research and development can contribute to provide more sustainable solutions.

Furthermore, referring to observation made by Delgado et al. (2001) which predicted that livestock revolution in developing countries, including ASEAN member countries of course, will continue until 2020 and will push the demand for livestock products which will make the developing countries stay as net importers. In the case of Indonesia with the tendency of increased import volume, in both feeder stock and beef, in fact has reduced the bargaining position of domestic beef cattle industry. However, by accelerating the integrated system to produce red meat in Indonesia, it is expected that the domestic demand for beef and sheep-goats can be managed properly. Animal feed and feeding will, therefore, become more important in the future to support the growing livestock ruminant industry. Such information was underlined by Makkar (2012) that estimates of feed resources and demands are needed to assess the fractions of food grain that is used for feed. Although livestock feed shortages have clearly constrained productivity in many countries, the impacts of feed shortages at national level have been poorly characterized due to the lack of national scale feed assessments. In addition, information on the availability of feed ingredients at the country level will enhance the efficiency and profitability of the animal feed industry and assist researchers to formulate sustainable feeding strategies. Such information would also be useful for determining the input-output relations for countries.

In order to achieve this, it is necessary that production systems become market-oriented, better regulated, and socially acceptable so that the right mix of incentives exists for the systems to intensify. In addition to this, new diversification as well as integrated systems will also be essential when intensification is no longer the primary option for developing the livestock subsector. This paper indicated that in 2013 beef cattle production cost to produce per kilogram live weight of beef cattle as well as sheep and goats in Indonesia were only at rank $4^{\text {th }}$ (beef) and rank $3^{\text {rd }}$ (sheep and goats) compared to other member countries.

\section{CONCLUSION}

Indonesia was only at the fourth rank for beef, third for sheep and goat and fourth for broiler production cost to produce per kilogram live weight compared to other member ASEAN countries. Consequently, Singapore, Malaysia, and Thailand have enjoyed the regional market under ASEAN Economic Communities (AEC), while Indonesia has not yet as that beneficial compared to those countries.

\section{REFERENCES}

Ambastha A, Momaya K. 2004. Competitiveness of firms: review of theory, frameworks, and models. Singapore Manag Rev. 26:45-61.

ASEAN. 2008. Blueprint ASEAN economic community. Jakarta (Indonesia): ASEAN. 
ASEAN. 2014. ASEAN statistical yearbook 2014. Jakarta (Indonesia): ASEAN

Bojnec Š, Fertő I. 2012. Complementarities of trade advantage and trade competitiveness measures. Appl Econ. 44:399-408.

CEIC Data. 2016. Agriculture in ASEAN. CEIC Data [Internet]. [cited 6 July 2016]. Available from: http://www.ceicdata.com/en/blog/agriculture-ASEAN

Daryanto A. 2007. Peningkatan daya saing industri peternakan. Jakarta (Indonesia): Permata Wacana Lestari.

Daryanto A. 2009. Dinamika daya saing industri peternakan. Bogor (Indonesia): IPB Press.

Daryanto A. 2010. Posisi daya saing pertanian Indonesia dan upaya peningkatannya. Dalam: Suradisastra K, Simatupang P, Hutabarat B, penyunting. Meningkatan Daya Saing Agribisnis Berorientasi Kesejahteraan Petani. Prosiding Seminar Nasional Peningkatan Daya Saing Agribisnis Berorientasi Kesejahteraan Petani. Bogor, 14 Oktober 2009. Bogor (Indonesia): PSEKP; p. 1-35.

Delgado CL, Rosegrant MW, Meijer S. 2001. Livestock to 2020: The revolution continues. In: Paper presented at the annual meetings of the International Agricultural Trade Research Consortium (IATRC). 18-19 January 2001. Washington DC (US): International Food Policy Research Institute. p. 1-38.

DGEC. 2015. Tree crop estate statistics of Indonesia. 20142016 oil palm. Jakarta (Indonesia): Directorate General of Estate Crops. Ministry of Agriculture.

European Union. 2015. World food consumption patterns Trends and drivers [Internet]. [cited 26 June 2016]. Available from: http://ec.europa.eu/agriculture/ Files/ markets-and-prices/..../06_en.pdf

Faizaty NE. 2014. Indonesian trade strategy for potential impacts of ASEAN economic community using gravity model approach. In: Erwidodo, Muhri K, Natawidjaja RS, Saptana, Hanani N, Darsono, Daryanto A, Oktaviani R, Rifin A, Feryanto, Putri TA, editors. Proceedings of the 17th National Conference and 16th Congress. Bogor, 28-29 August 2014. Bogor (Indonesia): Indonesian Agricultural Economic Association.

FAOSTAT. 2014. Agricultural price statistics. annual producer prices. FAO [Internet]. [cited 26 June 2016]. Available from: http://faostat3.fao.org

FAOSTAT. 2015. Livestock producer price. FAO [Internet]. [cited 26 June 2016]. Available from: http://faostat3.fao.org

Jabbar MA. 2015. ASEAN strategic plan of action for the livestock sub-sector, 2016-2020. Jakarta (Indonesia): ASEAN.

Kustiari R, Swastika DKS, Wahida, Simatupang P, Purwoto A, Nurasa T. 2010. Short term projection model for major agricultural products. Jakarta (Indonesia): IAARD Press.

Makkar HPS. 2012. Feed and fodder challenges for Asia and the Pacific, Asian livestock: challenges, opportunity, and response. In: Ahuja V, editor. Proceedings of International Policy Forum. Bangkok, 16-17 August 2012. Bangkok (Thailand): APHCA-ILRI-FAO.

Masters WA, Winter-Nelson A. 1995. Measuring the comparative advantage of agricultural activities: Domestic resource costs and the social cost-benefit ratio. Am J Agric Econ. 77:243-250.

Mathius IW. 2008. Pengembangan sapi potong berbasis industri kelapa sawit. Pengemban Inovasi Pertanian. 1:206-224.

Mathius IW. 2009. Produk samping industri kelapa sawit dan teknologi pengkayaan sebagai bahan pakan sapi yang terintegrasi. Dalam: Fagi AM, Subandriyo, Rusastra IW, penyunting. Sistem integrasi ternak tanaman: padi-sawit-kakao. Jakarta (Indonesia): LIPI Press. hlm. 65-109.

Matsumura K. 2011. Demand and supply structure for food in Asia. Sustainability. 3:363-395.

Monke EA, Pearson SK. 1989. The policy analysis matrix for agricultural development. New York (US): Cornell University Press.

OECD-FAO. 2015. Agricultural outlook 2015. Paris (France): OECD Publishing.

OECD. 2005. Glossary of statistical terms, definition and context [Internet]. [cited 25 July 2016]. Available from: https://stats.oecd.org/glossary

Orissa International 2017. Poultry sector in South East Asia. Iowa Economic Development Authority [Internet]. [cited 20 January 2017]. Available from:. https://www.iowaeconomicdevelopment.com/.../ieda/ PoultrySectorSouthEastAsia.pdf

Otte J. 2014. Bridging the technology gap for ASEAN livestock production. In: Panandam JM, Alimon AR, Yaakub H, Wahid H, Omar MA, Wan Khadijah WE, editors. Proceedings of the 1st ASEAN Regional Conference on Animal Production (1st ARCAP) and the 35th Annual Conference of Malaysian Society of Animal Production. Serawak, 4-6 June 2014. Serdang (Malaysia): Malaysian Society of Animal Production. p. 1-6.

Ready R, Roussanov N, Ward C. 2015. Commodity trade and the carry trade: A tale of two countries [Internet]. [cited 26 June 2016]. Available from: https://jacobslevycenter.wharton.upenn.edu/wpcontent/uploads/2015/05/Commodity-Trade-and-theCarry-Trade-4.3.15.pdf

Soedjana TD. 2011. Prevalensi usaha ternak tradisional dalam perspektif pembangunan peternakan menghadapi pasar global. Pengemban Inovasi Pertanian. 4:156173. 
Soedjana TD. 2013a. Sustainable livestock production in the perspective of national food security policy. Wartazoa. 23:23-30.

Soedjana TD. 2013b. Participation rate as a basis for measuring food security status of meat. Wartazoa. 23:166-175.

Soedjana TD, Diwyanto K. 2014. Principal thought for livestock development in Indonesia 2014-2019. In: Deciyanto, Rusastra IW, Bahri S, Subandriyo, Soedjana TD, editors. Direction and New Challenges for Agricultural Development in Indonesia. Jakarta (Indonesia): IAARD Press.

Sudaryanto T 2017. Palm oil and beef cattle integration system: A strategy to accelerate beef production in Indonesia [Internet]. [cited 20 January 2017]. Available from: http://ap.fftc.agnet.org/ap_db.php? id $=732 \&$ print $=1$

Tangendjaja B. 2010. Global competitiveness of poultry production in South East Asia countries. Wartazoa. 20:161-171. 